\title{
Hanford Apatite Treatability Test Report Errata: Apatite Mass Loading Calculation
}

\author{
JE Szecsody MD Williams \\ VR Vermeul MJ Truex
}

May 2014

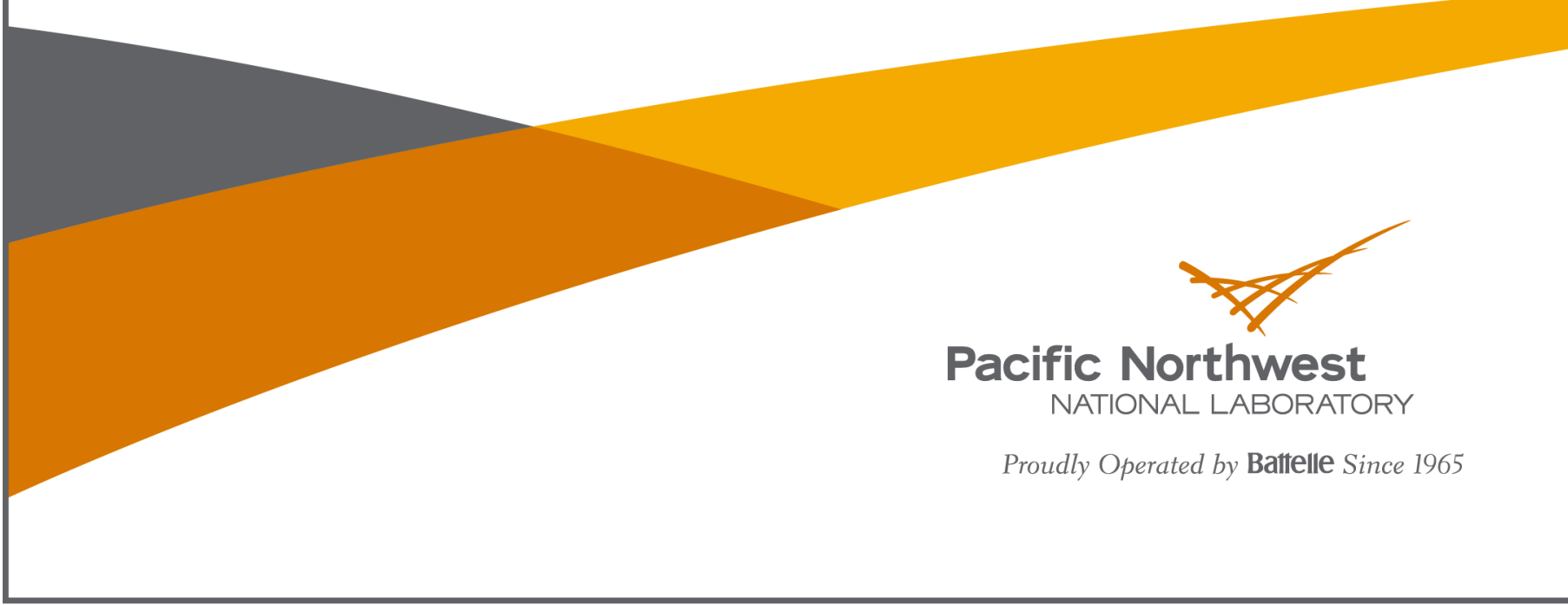




\title{
DISCLAIMER
}

This report was prepared as an account of work sponsored by an agency of the United States Government. Neither the United States Government nor any agency thereof, nor Battelle Memorial Institute, nor any of their employees, makes any warranty, express or implied, or assumes any legal liability or responsibility for the accuracy, completeness, or usefulness of any information, apparatus, product, or process disclosed, or represents that its use would not infringe privately owned rights. Reference herein to any specific commercial product, process, or service by trade name, trademark, manufacturer, or otherwise does not necessarily constitute or imply its endorsement, recommendation, or favoring by the United States Government or any agency thereof, or Battelle Memorial Institute. The views and opinions of authors expressed herein do not necessarily state or reflect those of the United States Government or any agency thereof.

\author{
PACIFIC NORTHWEST NATIONAL LABORATORY \\ operated by \\ BATTELLE \\ for the \\ UNITED STATES DEPARTMENT OF ENERGY \\ under Contract DE-AC05-76RL01830
}

Printed in the United States of America

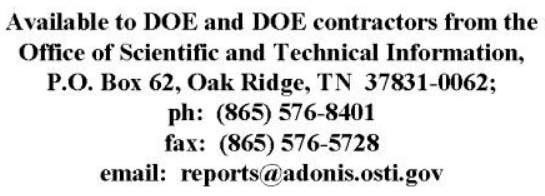

Available to the public from the National Technical Information Service 5301 Shawnee Rd., Alexandria, VA 22312 ph: (800) 553-NTIS (6847)

email: ordersantis.gov <http://www.ntis.gov/about/form.aspx> Online ordering: http://www.ntis.gov 


\title{
Hanford Apatite Treatability Test Report Errata: Apatite Mass Loading Calculation
}

\author{
JM Szecsody \\ MD Williams \\ VR Vermeul \\ MJ Truex
}

May 2014

Prepared for

the U.S. Department of Energy

under Contract DE-AC05-76RL01830

Pacific Northwest National Laboratory

Richland, Washington 99352 



\section{Contents}

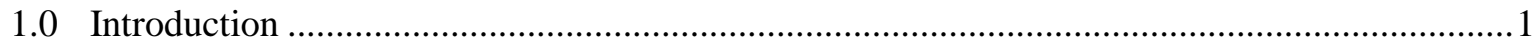

2.0 Apatite Loading Calculation..............................................................................................2

2.1 Mass of Apatite Needed to Sequester Strontium-90 in the Hanford 100-N Area ..............2

2.1.1 Baseline Chemical, Aquifer, and Barrier Configuration Information .....................2

2.1.2 Calculation of Initial Mass of Strontium in Barrier (aqueous + sorbed) .................4

2.1.3 Calculation of Strontium Mass Inflow to Barrier for 300 Years from Groundwater Flow...............................................................................

2.1.4 Total Strontium Mass: Initial Mass in Barrier + Mass Inflow from Groundwater

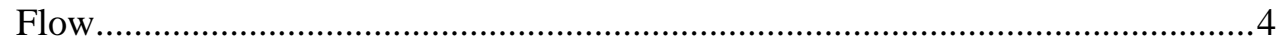

2.1.5 Estimated Apatite Mass Loading in the Barrier ................................................... 4

2.1.6 Estimated Phosphate Mass Loading in the Barrier.................................................5

2.2 Relative Strontium and Strontium-90 Concentrations ...................................................

2.3 Incorporation Rate of Strontium and Strontium-90 into Apatite...................................6

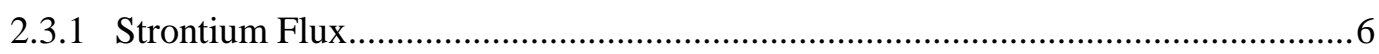

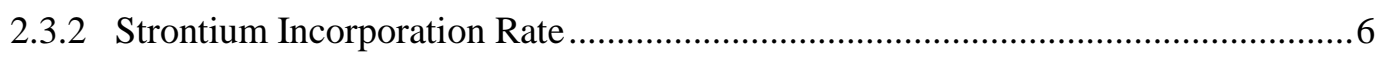

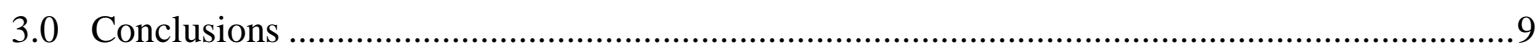

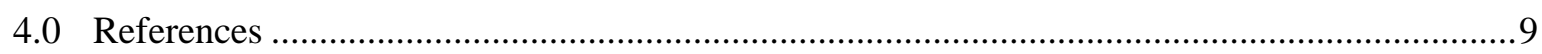

\section{Table}

1 Data and Calculations for Strontium Incorporation Rate 



\subsection{Introduction}

Efforts to reduce the flux of strontium-90 (Sr-90) to the Columbia River from past-practice liquid waste disposal sites have been underway since the early 1990s in the 100-N Area of the U.S. Department of Energy's (DOE's) Hanford Site in south-central Washington State. An evaluation of potential remedial alternatives identified a permeable reactive barrier (PRB) technology, using apatite as the means to sequester Sr-90, as a preferred approach for reducing Sr-90 flux to the Columbia River. The apatite technology sequesters Sr-90 by adsorption and subsequent incorporation of strontium ( $\mathrm{Sr}$ ) as a substitution for calcium within the apatite. A series of laboratory and field tests were conducted as part of development and demonstration of this technology (PNNL-19572, Vermeul et al. 2010; PNNL-19524, Szecsody et al. 2010; PNNL-18303, Szecsody et al. 2009; PNNL-17429, Williams et al. 2008, and PNNL-16891, Szecsody et al. 2007).

The objective of this errata report is to document an error in the apatite loading (i.e., treatment capacity) estimate reported in previous apatite treatability test reports and provide additional calculation details for estimating apatite loading and barrier longevity. The apatite treatability test final report (PNNL-19572; Vermeul et al. 2010) documents the results of the first field-scale evaluation of the injectable apatite PRB technology. The apatite loading value in units of milligram-apatite per gramsediment is incorrect in this and some other previous reports. The apatite loading in units of milligram phosphate per gram-sediment, however, is correct, and this is the unit used for comparison to field core sample measurements. Target apatite emplacement concentrations from the treatability test final report are based on calculations using average site properties and simplified Hanford 100-N Area groundwater flow conditions. The resulting target apatite content value was not developed as a regulatory performance metric for apatite barrier implementation; the treatability test performance metric had previously been defined as a $90 \%$ reduction in $\mathrm{Sr}-90$ concentration.

The apatite treatability test final report (PNNL-19572; Vermeul et al. 2010) makes recommendations regarding apatite amendment formulation and volume requirements based on 1) aqueous monitoring results and 2) phosphate $\left(\mathrm{PO}_{4}{ }^{3-}\right)$ content measurements made on post-treatment sediment core samples. These treatability test results are specific to the geohydrologic and geochemical conditions present along the 300-ft-long treatability test section of the barrier. It should be recognized that geohydrologic and geochemical conditions are likely to change along the full length of the barrier and thus, some adjustments to the implementation approach and apatite loading metric may be required.

The calculations of apatite loading in this errata report assume isotropic, homogeneous strontium (Sr, e.g., stable Sr-87) and Sr-90 concentrations that do not vary with time. In addition, average groundwater flow is assumed, so temporal and spatial variability in groundwater flow (and subsequently Sr-90 flux) are not taken into account. A modeling study would be needed to perform a quantitative evaluation of the influence that physical and geochemical heterogeneities and temporal groundwater flow variability have on the estimated apatite loading requirements. 


\subsection{Apatite Loading Calculation}

The Hanford 100-N permeable reactive barrier was designed to sequester $\mathrm{Sr}-90$ and $\mathrm{Sr}$ and uses a process to emplace apatite $\left[\mathrm{Ca}_{10}\left(\mathrm{PO}_{4}\right)_{6}(\mathrm{OH})_{2}\right]$ in the aquifer by injecting solutions that result in a controlled precipitation of apatite. Apatite minerals sequester elements into their molecular structures via isomorphic substitution, whereby elements of similar physical and chemical characteristics replace calcium, phosphate, or hydroxide in the hexagonal crystal structure (Hughes et al. 1989; Spence and Shi 2005). Apatite minerals are very stable and practically insoluble in water (Tofe 1998). Strontiapatite, $\mathrm{Sr}_{10}\left(\mathrm{PO}_{4}\right)_{6}(\mathrm{OH})_{2}$, which is formed by the complete substitution of calcium by $\mathrm{Sr}$ (or Sr-90), has a solubility product $\left(\mathrm{K}_{\mathrm{sp}}\right)$ of approximately $10^{-51}$, which makes it $10^{7}$ times less soluble than hydroxyapatite ( $\mathrm{K}_{\mathrm{sp}}$ of $10^{-44}$, Verbeek et al. 1977). The substitution of $\mathrm{Sr}$ for calcium in the crystal structure is thermodynamically favorable, and will proceed, provided the two elements coexist. Strontium substitution in natural apatites is as high as $11 \%$, depending on available $\mathrm{Sr}$ (Belousova et al. 2002). Synthetic apatites have been made with up to $40 \% \mathrm{Sr}$ substitution for calcium (Heslop et al. 2005).

\subsection{Mass of Apatite Needed to Sequester Strontium-90 in the Hanford 100-N Area}

The approach for estimating the apatite mass loading requirements includes an equilibrium calculation to account for adsorption and incorporation of $\mathrm{Sr}$ and $\mathrm{Sr}-90$ over the 300 year life of the barrier ( 10 half-lives of Sr-90 decay with a half-life of 29 years). A kinetic calculation is also used to account for the $\mathrm{Sr}$ incorporation rate compared with the Sr flux through the barrier. The calculations must consider the total $\mathrm{Sr}$ concentration with respect to substitution for $\mathrm{Ca}$ in apatite. Apatite cannot selectively uptake only Sr-90, so both Sr and Sr-90 mass need to be accounted for in estimating the mass of apatite needed in the barrier. The incorporation calculation is based on the substitution of $\mathrm{Sr}$ for $\mathrm{Ca}$ in the apatite structure.

The PRB is configured to be parallel to the river with injection of Ca-citrate-phosphate solution performed to achieve target phosphate concentrations out to a 15 -ft radius, making a $30-\mathrm{ft}(9.144 \mathrm{~m})$ thick PRB. The average groundwater flow is towards the river. The following assumptions and calculations are used to estimate the mass of apatite needed in the barrier:

\subsubsection{Baseline Chemical, Aquifer, and Barrier Configuration Information}

- Molecular weight of hydroxyapatite (apatite, $\left.\left[\mathrm{Ca}_{10}\left(\mathrm{PO}_{4}\right)_{6}(\mathrm{OH})_{2}\right]\right)=1004.62 \mathrm{~g} / \mathrm{mol}$.

- Mass of $\mathrm{Ca}$ in apatite $=401 \mathrm{~g} / \mathrm{mol}$.

- $\quad$ Mass of phosphate in apatite $=569.82 \mathrm{~g} / \mathrm{mol}$.

- Fraction $\mathrm{Sr}$ (and Sr-90) substitution for $\mathrm{Ca}$ in apatite $=0.10$.

- $\quad$ Average bulk density of $100-\mathrm{N}$ sediments $=1.78 \mathrm{~g} / \mathrm{cm}^{3}$.

- Average effective porosity of $100-\mathrm{N}$ sediments $=0.20 \mathrm{~cm}^{3}$ liquid $/ \mathrm{cm}^{3}$ total .

- Average distribution coefficient $\left(\mathrm{K}_{\mathrm{d}}\right)$ for $\mathrm{Sr}$ in whole sediment (Hanford/Ringold mixture) $=$ $14.75 \mathrm{~cm}^{3} / \mathrm{g}$. Whole sediment means the entire grain size distribution from gravel to clay. 
- Molecular weight of $10 \%$ Sr-substituted apatite $\left(\mathrm{SrCa}_{9}\left(\mathrm{PO}_{4}\right)_{6}(\mathrm{OH})_{2}\right)=1052.16 \mathrm{~g} / \mathrm{mol}$.

- Strontium average molecular weight $=87.62 \mathrm{~g} / \mathrm{mol}$.

- Phosphate molecular weight $=94.975 \mathrm{~g} / \mathrm{mol}$.

- Average groundwater strontium concentration $=0.20 \mathrm{mg} / \mathrm{L}$. (100-N area well data for 1987 through 1990 [11 wells] and 2002 through 2003 [30 wells] indicated an average Sr concentration of 0.225 and $0.245 \mathrm{mg} / \mathrm{L}$, respectively).

- Total life of barrier $=300$ years $(>10$ half-lives of Sr-90 decay such that the radioactivity decreases to $<0.1 \%$ of the original).

- Thickness of the apatite-laden barrier, perpendicular to the river $=30 \mathrm{ft}(9.144 \mathrm{~m})$ (i.e., a $15-\mathrm{ft}$ injection radius).

- Average groundwater velocity $=30 \mathrm{~cm} /$ day $(0.984 \mathrm{ft} /$ day $)$, toward the river.

- Selected cross-sectional area for a flow path through the barrier to the river $=1.0 \mathrm{~cm}^{2}$. 


\subsubsection{Calculation of Initial Mass of Strontium in Barrier (aqueous + sorbed)}

1. Sr retardation factor $\left(\mathrm{R}_{\mathrm{Sr}}\right)=1+\mathrm{K}_{\mathrm{d}} \times$ bulk density/porosity $=132.28$.

2. Volume of water in $1 \mathrm{~cm}^{2} \times 9.144$-m-long barrier section $=1.0 \mathrm{~cm}^{2} \times 914.4 \mathrm{~cm} \times 0.20 \mathrm{~cm}^{3}$ total $/ \mathrm{cm}^{3}$ liquid $=182.88 \mathrm{~cm}^{3}$ liquid.

3. $\mathrm{Sr}(\mathrm{g})$ in barrier $=182.88 \mathrm{~cm}^{3} \times$ liter $/ 1000 \mathrm{~cm}^{3} \times 0.20 \mathrm{mg} / \mathrm{L} \times 132\left(\mathrm{R}_{\mathrm{Sr}}\right) \times \mathrm{g} / 1000 \mathrm{mg}=0.00483 \mathrm{~g}$.

\subsubsection{Calculation of Strontium Mass Inflow to Barrier for $\mathbf{3 0 0}$ Years from Groundwater Flow}

1. Groundwater velocity $(\mathrm{cm} /$ year $)=30 \mathrm{~cm} /$ day $\times 365.25$ days $/$ year $=10957.5 \mathrm{~cm} /$ year.

2. Volumetric groundwater flow per year $=10957.5 \mathrm{~cm} /$ year $\times 1.0 \mathrm{~cm}^{2} \times 0.2 \mathrm{~cm}^{3}$ liquid $/ \mathrm{cm}^{3}$ total $=$ $2191.5 \mathrm{~cm}^{3} /$ year.

3. Sr mass inflow in 300 years $=2191.5 \mathrm{~cm}^{3} /$ year $\times$ liter $/ 1000 \mathrm{~cm}^{3} \times 0.2 \mathrm{mg} \mathrm{Sr} / \mathrm{L} \times \mathrm{g} / 1000 \mathrm{mg} \times$ 300 years $=0.13149 \mathrm{~g}$.

\subsubsection{Total Strontium Mass: Initial Mass in Barrier + Mass Inflow from Groundwater Flow}

1. Total Sr mass for treatment $=0.00483 \mathrm{~g}+0.13149 \mathrm{~g}=0.13632 \mathrm{~g} \mathrm{Sr}$.

2. Sr-apatite mass needed $=0.13632 \mathrm{~g} \mathrm{Sr} \times(1052.16 \mathrm{~g} / \mathrm{mol} 10 \% \mathrm{Sr}$-apatite $) /(87.62 \mathrm{~g} / \mathrm{mol} \mathrm{Sr})=$ $1.637 \mathrm{~g}$ Sr-apatite.

3. Apatite (with no $\mathrm{Sr}$ substitution) initially needed to incorporate all $\mathrm{Sr}=1.637 \mathrm{~g}$ Sr-apatite $\times$ $(1004.62 \mathrm{~g} / \mathrm{mol}$ apatite $) /(1052.16 \mathrm{~g} / \mathrm{mol} 10 \% \mathrm{Sr}$-apatite $) \times(1 \mathrm{~mol}$ apatite $/ 1 \mathrm{~mol} \mathrm{Sr}$-apatite $)=$ $1.563 \mathrm{~g}$ apatite.

\subsubsection{Estimated Apatite Mass Loading in the Barrier}

1. Sediment in barrier $\left(1 \mathrm{~cm}^{2} \times 914.4 \mathrm{~cm}\right)=1.0 \mathrm{~cm}^{2} \times 914.4 \mathrm{~cm} \times 2.78 \mathrm{~g} / \mathrm{cm}^{3}=1627.632 \mathrm{~g}$.

2. Minimum apatite in barrier (mg apatite per gram of sediment $)=1.563 \mathrm{~g}$ apatite $\times 1000 \mathrm{mg} / \mathrm{g}$ $/ 1627.632 \mathrm{~g}$ sed. $=0.96 \mathrm{mg}$ apatite/g sediment

It is this estimated value of apatite mass per mass of sediment that was incorrect in the earlier reports. The correct value is shown above as $0.96 \mathrm{mg}$ apatite/g sediment.

Note: The $0.96 \mathrm{mg}$ apatite/g of sediment loading in the barrier occupies some pore space in the aquifer. The aquifer porosity is about $20 \%$. Given the apatite crystal lattice dimensions of $9.38 \AA$ by $6.89 \AA$ (Berry and Mason, 1959), the $0.96 \mathrm{mg}$ apatite/g sediment would occupy less than $10 \%$ of the total pore space. This small decrease in porosity from added apatite may result in a small decrease in permeability within the PRB. 


\subsubsection{Estimated Phosphate Mass Loading in the Barrier}

1. Minimum phosphate in barrier (mg phosphate per gram of sediment) $=0.96 \mathrm{mg}$ apatite/g sediment $\times 569.83 \mathrm{~g} \mathrm{PO}_{4} / \mathrm{mol} / 1004.62 \mathrm{~g}$-apatite $/ \mathrm{mol}=0.54 \mathrm{mg} \mathrm{PO} / \mathrm{g}$ sediment

This estimated value of phosphate mass per mass of sediment was correct in the earlier reports and is the basis for interpreting the post apatite injection sediment characterization data. However, the corresponding calculation of phosphate concentration in the injection solution required to obtain this loading was incorrect and needs to be updated. In previous reports, a value of $90 \mathrm{mM}$ was used. The correct value for the one pore volume formulation concentration, based on the target phosphate content ( $0.54 \mathrm{mg} \mathrm{PO} / \mathrm{g}$ sediment), is $51 \mathrm{mM}$ of phosphate precipitated in sediment with no retardation (assuming all injected $\mathrm{PO}_{4}$ precipitates). Assuming a phosphate retardation factor of 2.0 during injections (based on laboratory and field calcium-citrate-phosphate injections), the target phosphate content would correspond to a two pore volume (with a $9.1 \mathrm{~m}$ diameter pore volume) concentration of $26 \mathrm{mM}$ phosphate. The high-concentration injection solution was specified at $40 \mathrm{mM}$ phosphate as a result of phosphate solubility limits and other technical considerations, and therefore, includes a safety factor to reach the target phosphate (and apatite) mass loading in the sediment.

\subsection{Relative Strontium and Strontium-90 Concentrations}

Although Sr-90 is the target contaminant for sequestration by the apatite barrier, because incorporation of $\mathrm{Sr}-90$ into apatite is not selective for that specific isotope, the barrier design is based on 1) incorporation of all $\mathrm{Sr}$ initially present within the barrier domain plus 2) the $\mathrm{Sr}$ that flows into the barrier under natural groundwater flow conditions over the next 300 years. The relative concentration of Sr-90 (in $\mathrm{mg} / \mathrm{L}$ ) is calculated to compare it with the $0.2 \mathrm{mg} / \mathrm{L}$ average $\mathrm{Sr}$ groundwater concentration that was used to estimate the mass of apatite needed for the barrier.

$$
\begin{aligned}
& \text { Variables } \\
& \mathrm{A}=\text { activity } ; \mathrm{Ci}=3.7 \times 10^{10} \mathrm{~Bq} \\
& \mathrm{~L}=\text { radioactive decay constant in } 1 / \text { seconds } \\
& \mathrm{Na}=\text { Avogadro's number }=6.022 \times 10^{23} \\
& \mathrm{M}=\text { atomic mass }(\mathrm{g} / \mathrm{mol})=90 \mathrm{~g} / \mathrm{mol} \\
& \mathrm{m}=\text { mass/activity }(\mathrm{g} / \mathrm{Ci})
\end{aligned}
$$

\section{Calculation}

$$
\begin{aligned}
& \mathrm{m}=\mathrm{A} \times \mathrm{M} /(\mathrm{L} \times \mathrm{Na}),\left(\text { for } 1 \mathrm{Ci}, \mathrm{A}=3.7 \times 10^{10} \mathrm{~Bq}\right) \\
& \mathrm{L}=\ln (2) /(29 \text { years } \times 365.25 \text { days } / \mathrm{yr} \times 24 \mathrm{~h} / \mathrm{day} \times 3600 \mathrm{sec} / \mathrm{h})=7.57 \times 10^{-10} / \mathrm{sec} . \\
& \mathrm{m}=\left(3.7 \times 10^{10} \mathrm{~Bq} \times 90 \mathrm{~g} / \mathrm{mol}\right) /\left(7.57 \times 10^{-10} / \mathrm{sec} \times 6.022 \times 10^{23}\right)=0.0073 \mathrm{~g} \mathrm{Sr}-90 / \mathrm{Ci} \\
& \text { Specific activity }=137 \mathrm{Ci} / \mathrm{g}(\mathrm{Sr}-90) \times \mathrm{g} / 1000 \mathrm{mg} \times 10^{12} \mathrm{pCi} / \mathrm{Ci}=1.37 \times 10^{11} \mathrm{pCi} / \mathrm{mg} \mathrm{Sr}-90 . \\
& \text { Example groundwater concentration relevant to } 100-N \text { Area }: 20,000 \mathrm{pCi} / \mathrm{L} \\
& \quad 20,000 \mathrm{pCi} / \mathrm{L} / 1.37 \times 10^{11} \mathrm{pCi} / \mathrm{mg} \mathrm{Sr}-90=1.46 \times 10^{-7} \mathrm{mg} / \mathrm{L} \mathrm{Sr}-90
\end{aligned}
$$

Thus, a Sr-90 concentration of $20,000 \mathrm{pCi} / \mathrm{L}$ corresponds to a $\mathrm{Sr}-90$ concentration of $1.5 \times 10^{-7} \mathrm{mg} / \mathrm{L}$, much lower than the total $\mathrm{Sr}$ concentration of about $0.2 \mathrm{mg} / \mathrm{L}$. 


\subsection{Incorporation Rate of Strontium and Strontium-90 into Apatite}

The second factor that controls the amount of apatite needed to sequester $\mathrm{Sr}-90$ is the rate of $\mathrm{Sr}-90$ incorporation into apatite. For the PRB to be effective, the flux of Sr and Sr-90 into the barrier needs to be slower than the rate of $\mathrm{Sr}$ and $\mathrm{Sr}-90$ incorporation into apatite. A number of laboratory experiments have been conducted to clearly define the rate at which $\mathrm{Sr}$ (and Sr-90) is incorporated into the crystal structure of apatite (Szecsody et al. 2009). To evaluate whether Sr incorporation rates into apatite will support an effective field-scale reactive barrier in the Hanford 100-N Area, the Sr flux into the barrier was compared with laboratory-derived $\mathrm{Sr}$ incorporation rates scaled to the field application of the apatite barrier. The apatite mass loading in sediment for the field-scale barrier was assumed to be the target 0.96 mg apatite/g of sediment (0.54 $\mathrm{mg} \mathrm{PO}_{4} / \mathrm{g}$ of sediment), as derived in Section 2.1.

\subsubsection{Strontium Flux}

The Sr flux will be highest just after barrier emplacement because of the presence of the high concentration Ca-citrate-phosphate solution in the groundwater that decreases $\mathrm{Sr}$ adsorption to sediments for a period of time. Ion exchange calculations show nearly zero adsorption of $\mathrm{Sr}$ in the presence of the injection solution. As the constituents in the injection solution precipitate and the injection solution mixes with surrounding groundwater, the ionic strength decreases, $\mathrm{Sr}$ adsorption increases, and the aqueous $\mathrm{Sr}$ flux decreases. The bounding cases for $\mathrm{Sr}$ flux are calculated below.

1. Long-term Sr flux (natural groundwater conditions) $=$ $\left((0.2 \mathrm{mg}-\mathrm{Sr} / \mathrm{L}) / 1000 \mathrm{~cm}^{3} / \mathrm{L}\right) /(87.62 \mathrm{mg} / \mathrm{mmol}) \times 0.2$ (porosity) $\times 30 \mathrm{~cm} / \mathrm{d}$ (groundwater velocity) / $132.28\left(\mathrm{R}_{\mathrm{Sr}}\right)=1.03 \times 10^{-7} \mathrm{mmol} \mathrm{Sr} /$ day $/ \mathrm{cm}^{2}$

2. Short-term post-emplacement $\mathrm{Sr}$ flux (assume no retardation $)=$ $\left((0.2 \mathrm{mg}-\mathrm{Sr} / \mathrm{L}) / 1000 \mathrm{~cm}^{3} / \mathrm{L}\right) /(87.62 \mathrm{mg} / \mathrm{mmol}) \times 0.2$ (porosity) $\times 30 \mathrm{~cm} / \mathrm{d}$ (groundwater velocity) $=1.36 \times 10^{-5} \mathrm{mmol} \mathrm{Sr} /$ day $/ \mathrm{cm}^{2}$

These calculations show a variation in flux of about two orders of magnitude because of the adsorption conditions. A Sr flux of $1.36 \times 10^{-6} \mathrm{mmol} \mathrm{Sr} / \mathrm{day} / \mathrm{cm}^{2}$, which is one order of magnitude less than the maximum value, was used as a nominal value for comparison with the apatite Sr incorporation rate. This nominal value represents a simplified and conservative estimate that recognizes that 1) early $\mathrm{Sr}$ flux rates will be larger than the long-term values and 2) the assumption of no retardation in early times is overly conservative when estimating $\mathrm{Sr}$ flux over the life of the barrier.

\subsubsection{Strontium Incorporation Rate}

The strontium incorporation rate was evaluated based on data collected in batch laboratory tests with solid apatite and groundwater spiked with $\mathrm{Sr}$ (Szecsody et al. 2009). In these tests, dissolved Sr was present in the supernatant in excess of the apatite adsorption and incorporation capacity. Data for changes in dissolved $\mathrm{Sr}$ concentration were collected periodically over a period of 6000 hours (>8 months). The initial decrease in dissolved $\mathrm{Sr}$ concentration is attributed to adsorption. Once adsorption sites are filled, continued decreases in dissolved $\mathrm{Sr}$ will occur as adsorbed $\mathrm{Sr}$ is incorporated into the apatite and a new adsorption site becomes available. Because adsorption is much faster than incorporation, the incorporation rate will control the rate of $\mathrm{Sr}$ concentration decline in the aqueous phase. The rate of 
incorporation, based on changes in dissolved $\mathrm{Sr}$ concentration over time, was calculated from data at different time points during the experiment and an average incorporation rate was calculated. Results from five different experiments were analyzed and averaged to obtain an average and range for the laboratory incorporation rate. The laboratory rate was then scaled to account for the apatite loading in the field-scale barrier. Data and calculations are shown in Table 1.

For the target apatite mass loading of $0.96 \mathrm{mg}$ apatite per gram of sediment $\left(0.54 \mathrm{mg} \mathrm{PO}_{4}\right.$ per gram of sediment), the field-scaled Sr incorporation rate has an average value of $2.28 \times 10^{-5} \mathrm{mmol} \mathrm{Sr} / \mathrm{day} / \mathrm{cm}^{2}$ with a range from $2.84 \times 10^{-5} \mathrm{mmol} \mathrm{Sr} /$ day $/ \mathrm{cm}^{2}$ to $1.71 \times 10^{-5} \mathrm{mmol} \mathrm{Sr} /$ day $/ \mathrm{cm}^{2}$ based on one standard deviation above and below the average. The calculated average incorporation rate is greater than the calculated nominal $\left(1.36 \times 10^{-6} \mathrm{mmol} \mathrm{Sr} / \mathrm{day} / \mathrm{cm}^{2}\right)$, short-term maximum $\left(1.36 \times 10^{-5} \mathrm{mmol} \mathrm{Sr} / \mathrm{day} / \mathrm{cm}^{2}\right)$, and long-term $\left(1.03 \times 10^{-7} \mathrm{mmol} \mathrm{Sr} / \mathrm{day} / \mathrm{cm}^{2}\right) \mathrm{Sr}$ flux into the barrier (i.e., from 2 to 200 times the estimated $\mathrm{Sr}$ flux through the barrier). Therefore, on a rate basis, all of the $\mathrm{Sr}$ (and $\mathrm{Sr}-90$ ) should be sequestered by the apatite in the barrier. It should be noted that groundwater velocity can vary over time from the average used in these calculations and that field performance will also depend on presence of flow heterogeneities and the actual apatite loading in the barrier. Thus, field performance monitoring of the barrier is necessary, though these scoping-level design calculations show that the target apatite loading is sufficient to sequester the nominal Sr flux. 
Table 1. Data and Calculations for Strontium Incorporation Rate

\begin{tabular}{|c|c|c|c|c|c|c|c|c|c|c|c|c|c|c|c|c|}
\hline & \multicolumn{3}{|c|}{ Exp. T-69, $\mathrm{T}=22^{\circ} \mathrm{C}$} & \multicolumn{4}{|c|}{ Exp. $\mathrm{T}-73, \mathrm{~T}=22^{\circ} \mathrm{C}$} & \multicolumn{3}{|c|}{ Exp. $\mathrm{T}-74, \mathrm{~T}=42^{\circ} \mathrm{C}$} & \multicolumn{3}{|c|}{ Exp. $\mathrm{T}-75, \mathrm{~T}=62^{\circ} \mathrm{C}$} & \multicolumn{3}{|c|}{ Exp. T-76, $\mathrm{T}=82^{\circ} \mathrm{C}$} \\
\hline $\begin{array}{l}\text { time } \\
(\mathrm{h})^{\mathrm{a}}\end{array}$ & $\mathrm{Sr}(\mathrm{mmol})$ & $\begin{array}{l}\mathrm{Sr} \text { (mmol } \\
\text { in apatite) }\end{array}$ & $\begin{array}{c}\text { Incorp. } \\
\text { rate }^{\mathrm{b}} \\
(\mathrm{mmol} / \mathrm{d})\end{array}$ & $\begin{array}{l}\text { time } \\
(\mathrm{h})^{\mathrm{c}}\end{array}$ & $\mathrm{Sr}(\mathrm{mmol})$ & $\begin{array}{l}\mathrm{Sr} \text { (mmol } \\
\text { in apatite) }\end{array}$ & $\begin{array}{c}\text { Incorp. } \\
\text { rate } \\
(\mathrm{mmol} / \mathrm{d})\end{array}$ & $\begin{array}{c}\mathrm{Sr} \\
(\mathrm{mmol})\end{array}$ & $\begin{array}{l}\mathrm{Sr} \text { (mmol } \\
\text { in apatite) }\end{array}$ & $\begin{array}{c}\text { Incorp. } \\
\text { rate } \\
(\mathrm{mmol} / \mathrm{d})\end{array}$ & $\mathrm{Sr}(\mathrm{mmol})$ & $\begin{array}{l}\mathrm{Sr} \text { (mmol } \\
\text { in apatite) }\end{array}$ & $\begin{array}{c}\text { Incorp. } \\
\text { rate } \\
(\mathrm{mmol} / \mathrm{d})\end{array}$ & $\mathrm{Sr}(\mathrm{mmol})$ & $\begin{array}{c}\mathrm{Sr} \text { (mmol } \\
\text { in apatite) }\end{array}$ & $\begin{array}{c}\text { Incorp. } \\
\text { rate } \\
(\mathrm{mmol} / \mathrm{d})\end{array}$ \\
\hline 0.0 & $6.00 \mathrm{E}-05$ & & & 0.0 & $6.00 \mathrm{E}-05$ & & & $6.00 \mathrm{E}-05$ & & & $6.00 \mathrm{E}-05$ & & & $6.00 \mathrm{E}-05$ & & \\
\hline 3.3 & $3.06 \mathrm{E}-05$ & Adsorp. $^{\text {d }}$ & Adsorp. & 3.5 & $5.05 \mathrm{E}-05$ & Adsorp. & Adsorp. & $4.75 \mathrm{E}-05$ & Adsorp. & Adsorp. & $4.57 \mathrm{E}-05$ & Adsorp. & Adsorp. & $4.23 \mathrm{E}-05$ & Adsorp. & Adsorp. \\
\hline 23.5 & $2.90 \mathrm{E}-05$ & Adsorp. & Adsorp. & 23.6 & $4.35 \mathrm{E}-05$ & Adsorp. & Adsorp. & $4.25 \mathrm{E}-05$ & Adsorp. & Adsorp. & $3.79 \mathrm{E}-05$ & Adsorp. & Adsorp. & $3.27 \mathrm{E}-05$ & Adsorp. & Adsorp. \\
\hline 75.0 & $2.59 \mathrm{E}-05$ & $3.07 \mathrm{E}-06$ & $1.43 \mathrm{E}-06$ & 75.0 & $4.42 \mathrm{E}-05$ & Adsorp. & Adsorp. & 3.91E-05 & $3.33 \mathrm{E}-06$ & $1.55 \mathrm{E}-06$ & $3.44 \mathrm{E}-05$ & $3.56 \mathrm{E}-06$ & $1.66 \mathrm{E}-06$ & $2.94 \mathrm{E}-05$ & $3.31 \mathrm{E}-06$ & $1.54 \mathrm{E}-06$ \\
\hline 316.0 & $2.55 \mathrm{E}-05$ & $3.53 \mathrm{E}-06$ & $2.89 \mathrm{E}-07$ & 316.3 & 3.97E-05 & $4.50 \mathrm{E}-06$ & $4.48 \mathrm{E}-07$ & $3.59 \mathrm{E}-05$ & $6.50 \mathrm{E}-06$ & $5.33 \mathrm{E}-07$ & $3.09 \mathrm{E}-05$ & $7.03 \mathrm{E}-06$ & $5.77 \mathrm{E}-07$ & $2.53 \mathrm{E}-05$ & $7.36 \mathrm{E}-06$ & $6.04 \mathrm{E}-07$ \\
\hline 651.9 & $2.57 \mathrm{E}-05$ & $3.30 \mathrm{E}-06$ & $1.26 \mathrm{E}-07$ & 652.1 & $3.81 \mathrm{E}-05$ & $6.10 \mathrm{E}-06$ & $2.54 \mathrm{E}-07$ & $3.44 \mathrm{E}-05$ & $8.05 \mathrm{E}-06$ & 3.07E-07 & $2.99 \mathrm{E}-05$ & 7.99E-06 & $3.05 \mathrm{E}-07$ & $2.54 \mathrm{E}-05$ & $7.30 \mathrm{E}-06$ & $2.79 \mathrm{E}-07$ \\
\hline 1011.9 & $2.42 \mathrm{E}-05$ & $4.75 \mathrm{E}-06$ & $1.15 \mathrm{E}-07$ & 1012.1 & $3.73 \mathrm{E}-05$ & $6.97 \mathrm{E}-06$ & $1.79 \mathrm{E}-07$ & $3.34 \mathrm{E}-05$ & $9.09 \mathrm{E}-06$ & $2.21 \mathrm{E}-07$ & $2.82 \mathrm{E}-05$ & $9.66 \mathrm{E}-06$ & $2.35 \mathrm{E}-07$ & $2.54 \mathrm{E}-05$ & $7.28 \mathrm{E}-06$ & $1.77 \mathrm{E}-07$ \\
\hline 1319.5 & $2.46 \mathrm{E}-05$ & $4.42 \mathrm{E}-06$ & $8.19 \mathrm{E}-08$ & 1319.7 & $3.80 \mathrm{E}-05$ & $6.21 \mathrm{E}-06$ & $1.20 \mathrm{E}-07$ & $3.42 \mathrm{E}-05$ & $8.26 \mathrm{E}-06$ & $1.53 \mathrm{E}-07$ & $2.95 \mathrm{E}-05$ & $8.38 \mathrm{E}-06$ & $1.55 \mathrm{E}-07$ & $2.52 \mathrm{E}-05$ & $7.43 \mathrm{E}-06$ & $1.38 \mathrm{E}-07$ \\
\hline 1679.8 & $2.51 \mathrm{E}-05$ & $3.89 \mathrm{E}-06$ & $5.64 \mathrm{E}-08$ & 1680.0 & $3.72 \mathrm{E}-05$ & 7.07E-06 & $1.06 \mathrm{E}-07$ & $3.34 \mathrm{E}-05$ & $9.02 \mathrm{E}-06$ & $1.31 \mathrm{E}-07$ & $2.90 \mathrm{E}-05$ & $8.95 \mathrm{E}-06$ & $1.30 \mathrm{E}-07$ & $2.51 \mathrm{E}-05$ & $7.54 \mathrm{E}-06$ & $1.09 \mathrm{E}-07$ \\
\hline 2039.9 & $2.51 \mathrm{E}-05$ & $3.83 \mathrm{E}-06$ & $4.56 \mathrm{E}-08$ & 2040.1 & $3.75 \mathrm{E}-05$ & $6.72 \mathrm{E}-06$ & $8.21 \mathrm{E}-08$ & $3.35 \mathrm{E}-05$ & $8.96 \mathrm{E}-06$ & $1.07 \mathrm{E}-07$ & $2.93 \mathrm{E}-05$ & $8.66 \mathrm{E}-06$ & $1.03 \mathrm{E}-07$ & $2.46 \mathrm{E}-05$ & $8.01 \mathrm{E}-06$ & $9.53 \mathrm{E}-08$ \\
\hline 2738.9 & $2.51 \mathrm{E}-05$ & $3.88 \mathrm{E}-06$ & $3.43 \mathrm{E}-08$ & 2739.1 & $3.59 \mathrm{E}-05$ & $8.38 \mathrm{E}-06$ & $7.55 \mathrm{E}-08$ & $3.34 \mathrm{E}-05$ & $9.02 \mathrm{E}-06$ & 7.97E-08 & $2.84 \mathrm{E}-05$ & $9.52 \mathrm{E}-06$ & $8.41 \mathrm{E}-08$ & $2.49 \mathrm{E}-05$ & 7.73E-06 & $6.84 \mathrm{E}-08$ \\
\hline 6194.1 & $1.70 \mathrm{E}-05$ & $1.20 \mathrm{E}-05$ & $4.66 \mathrm{E}-08$ & 6194.2 & $2.38 \mathrm{E}-05$ & $2.04 \mathrm{E}-05$ & $8.02 \mathrm{E}-08$ & $2.33 \mathrm{E}-05$ & $1.92 \mathrm{E}-05$ & $7.46 \mathrm{E}-08$ & $1.95 \mathrm{E}-05$ & $1.84 \mathrm{E}-05$ & $7.15 \mathrm{E}-08$ & $1.71 \mathrm{E}-05$ & $1.55 \mathrm{E}-05$ & $6.04 \mathrm{E}-08$ \\
\hline \multicolumn{3}{|c|}{ average (lab) } & $2.47 \mathrm{E}-07$ & & & & $1.68 \mathrm{E}-07$ & & & $3.51 \mathrm{E}-07$ & & & $3.69 \mathrm{E}-07$ & & & $3.41 \mathrm{E}-07$ \\
\hline \multicolumn{3}{|c|}{$\mathrm{mmol} / \mathrm{d} / \mathrm{mg}$-apatite $(\mathrm{lab})^{\mathrm{e}}$} & $1.41 \mathrm{E}-08$ & & & & $9.59 \mathrm{E}-09$ & & & $2.01 \mathrm{E}-08$ & & & $2.11 \mathrm{E}-08$ & & & $1.95 \mathrm{E}-08$ \\
\hline \multicolumn{3}{|c|}{$\mathrm{mmol} / \mathrm{d} / \mathrm{g}$-sediment (field) ${ }^{\mathrm{f}}$} & $1.36 \mathrm{E}-08$ & & & & $9.21 \mathrm{E}-09$ & & & $1.93 \mathrm{E}-08$ & & & $2.02 \mathrm{E}-08$ & & & $1.87 \mathrm{E}-08$ \\
\hline \multicolumn{3}{|c|}{$\mathrm{mmol} / \mathrm{d} / \mathrm{cm}^{\wedge} 2{\text { (field })^{\mathrm{g}}}$} & $2.21 \mathrm{E}-05$ & & & & $1.50 \mathrm{E}-05$ & & & $3.13 \mathrm{E}-05$ & & & $3.29 \mathrm{E}-05$ & & & $3.05 \mathrm{E}-05$ \\
\hline \multicolumn{3}{|c|}{$\mathrm{mmol} / \mathrm{d} / \mathrm{cm}^{\wedge} 2$ at $16 \mathrm{C}(\text { field })^{\mathrm{h}}$} & $2.09 \mathrm{E}-05$ & & & & $1.38 \mathrm{E}-05$ & & & $2.61 \mathrm{E}-05$ & & & $2.77 \mathrm{E}-05$ & & & $2.53 \mathrm{E}-05$ \\
\hline
\end{tabular}

${ }^{a}$ Time for experiment T-69.

${ }^{\mathrm{b}}$ Incorporation rate of strontium into apatite.

${ }^{\mathrm{c}}$ Time for experiments T-73 through T-76.

${ }^{\mathrm{d}}$ Strontium changes for these time points are interpreted as due to adsorption.

${ }^{\mathrm{e}}$ Accounts for $17.5 \mathrm{mg}$ apatite in laboratory experiment.

${ }^{\mathrm{f}}$ Accounts for the target value of $0.96 \mathrm{mg}$-apatite/g-sediment in the field application.

${ }^{\mathrm{g}}$ Accounts for the $1628 \mathrm{~g}$-sediment $/ \mathrm{cm}^{2}$-barrier cross sectional area.

${ }^{\mathrm{h}}$ Temperature correction to $16^{\circ} \mathrm{C}$ based on a linear regression slope of the laboratory rates. 


\subsection{Conclusions}

An apatite mass loading of $0.96 \mathrm{mg}$ apatite per gram of sediment $\left(0.54 \mathrm{mg} \mathrm{PO}_{4}\right.$ per gram of sediment $)$ is needed to remove $\mathrm{Sr}$ (and $\mathrm{Sr}-90$ ) from groundwater over the next 300 years, assuming average conditions (calculation assumptions are listed in Section 2.0). This average apatite mass loading was based on $10 \% \mathrm{Sr}$ substitution for $\mathrm{Ca}$ in apatite. This apatite mass loading is also sufficient to sequester the $\mathrm{Sr}$ flux into the barrier based on a rate analysis comparing the $\mathrm{Sr}$ flux to the $\mathrm{Sr}$ incorporation rate in apatite. This errata report was used to revise previous PNNL reports (PNNL-19572, Vermeul et al. 2010; PNNL-19524, Szecsody et al. 2010; PNNL-18303, Szecsody et al. 2009; PNNL-17429, Williams et al. 2008, and PNNL-16891, Szecsody et al. 2007). Note that, in some portions of these previous reports, different apatite loading and incorporation values are shown because of different assumptions used in the calculations or because the calculations were for different applications of the data; these portions of the previous reports were not revised.

\subsection{References}

Berry, L., and B. Mason. 1959. Mineralogy. W. Freeman and Company, San Francisco, CA.

Belousova EA, WL Griffin, SY O'Reilly, and NI Fisher. 2002. "Apatite as an Indicator Mineral for Mineral Exploration: Trace-Element Compositions and Their Relationship to Host Rock Type." Journal of Geochemical Exploration 76:45-69.

Heslop DD, Y Bi, AA Baig, M Otsuka, and WI Higuchi. 2005. "A Comparative Study of the Metastable Equilibrium Solubility Behavior of High-Crystallinity and Low-Crystallinity Carbonated Apatites Using $\mathrm{pH}$ and Solution Strontium as Independent Variables." Journal of Colloid and Interface Science 289:14-25.

Hughes JM, M Cameron, and KD Crowley. 1989. "Structural Variations in Natural F, OH, and Cl Apatites." American Mineralogist 74:870-876.

Spence RD and C Shi. 2005. Stabilization and Solidification of Hazardous, Radioactive, and Mixed Wastes. CRC Press, Boca Raton, Florida.

Tofe AJ. 1998. “Chemical Decontamination Using Natural or Artificial Bone.” US Patent 5,711,015.

Szecsody J, C Burns, R Moore, J Fruchter, V Vermeul, D Girvin, J Phillips, and M Williams. 2007. Hanford 100-N Area Apatite Emplacement: Laboratory Results of Ca-Citrate-PO $\mathrm{O}_{4}$ Solution Injection and Sr-90 Immobilization in 100-N Sediments. PNNL-16891, Pacific Northwest National Laboratory, Richland, Washington.

Szecsody J, M Rockhold, M Oostrom, R Moore, C Burns, M Williams, L Zhong, J Fruchter, J McKinley, V Vermeul, M Covert, T Wietsma, A Breshears, and B Garcia. 2009. Sequestration of Sr-90 Subsurface Contamination in the Hanford 100-N Area by Surface Infiltration of a Ca-Citrate-Phosphate Solution. PNNL-18303, Pacific Northwest National Laboratory, Richland, Washington. 
Szecsody J, V Vermeul, J Fruchter, M Williams, M Rockhold, N Qafoku, and J Phillips. 2010. Hanford 100-N Area In Situ Apatite and Phosphate Emplacement by Groundwater and Jet Injection:

Geochemical and Physical Core Analysis. PNNL-19524, Pacific Northwest National Laboratory, Richland, Washington.

Verbeek RMH, M Hauben, HP Thun, and F Verbeek. 1977. "Solubility and Solution Behavior of Strontium hydroxyapatite." Zeitschrift für Physikalische Chemie (Wiesbaden). 108(2):203-215.

Vermeul V, J Szecsody, B Fritz, M Williams, and J Fruchter. 2010. 100-NR-2 Apatite Treatability Test FY09 Status: High-Concentration Calcium-Citrate-Phosphate Solution Injection for In Situ Strontium-90 Immobilization. PNNL-19572, Pacific Northwest National Laboratory, Richland, Washington.

Williams, MD, BG Fritz, DP Mendoza, ML Rockhold, PD Thorne, YL Xie, BN Bjornstad, RD Mackley, JE Szecsody, and VR Vermeul. 2008. 100-NR-2 Apatite Treatability Test: Low Concentration CalciumCitrate-Phosphate Solution Injection for In Situ Strontium-90 Immobilization. PNNL-17429, Pacific Northwest National Laboratory, Richland, Washington. 


\section{Distribution}

No. of

Copies

3 CH2M Hill Plateau Remediation Company Bill Faught

Virginia Rohay

Art Lee

(PDF)
No. of

$\underline{\text { Copies }}$

5 Local Distribution

Pacific Northwest National Laboratory

Dawn Wellman

Jim Szecsody

Vince Vermeul

(PDF)

Mark Williams

Mike Truex
(PDF)

(PDF)

(PDF)

(PDF)

Distr.1 




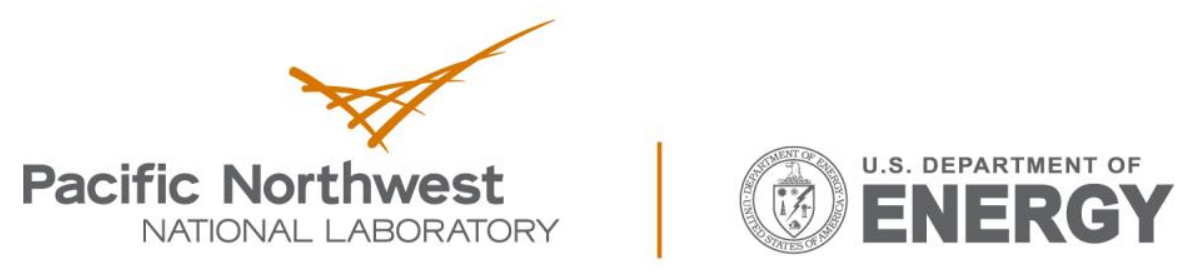

Proudly Operated by Battelle Since 1965

902 Battelle Boulevard

P.O. Box 999

Richland, WA 99352

1-888-375-PNNL (7665)

www.pnnl.gov 